\title{
THE NINETEENTH CENTURY WESTERN TRAVELLERS’ CONCEPTION OF THE HARIMM: RESTORING THE CULTURAL COMPLEXITY OF THE HִIJĀB IN ARCHITECTURE
}

\author{
Faredah Mohsen al-Murahhem
}

\author{
Art Education Department, Umm al-Qura University, \\ al-Zahir St., Makkah, Saudi Arabia \\ e-mail: Fmurahhem@hotmail.com
}

\begin{abstract}
This paper examines $19^{\text {th }}$ century Western travellers' understanding of the harīm. Focusing in particular on visual depictions, it investigates the misconception and misrepresentation of the harīm in Orientalists' paintings and Western culture, using thework of the artist John Frederick Lewis as a main case study. Arguing that such representations oversimplify and fantasise sacred Islamic cultural experience, this paper, as a counterpoint, restores a detailed understanding of the harīm and defines its wider Islamic implication within Arabic culture. Applying etymology and Islamic scripture to the study of architectural design, this study explores the centrality of the concept of hijāb (veil) to the organisation of physical space for women in the Islamic home. Written from the perspective of an Arabic Muslim woman, this study seeks to explore the concept of the harim from the "Others" perspective.
\end{abstract}

Keyword: Western travellers, Orientalists, Muslim women, ḥarīm, Arabic culture

\begin{abstract}
Abstrak
Makalah ini membahas pemahaman penjelajah Barat di abad ke-19 Barat mengenai ḥarīm. Berfokus secara khusus pada penggambaran visual, makalah ini menyelidiki kesalahpahaman dan kekeliruan konseptual dari ḥarīm di dalam lukisan Orientalis dan budaya Barat, menggunakan karya seniman John Frederick Lewis sebagai studi kasus utama. Dengan alasan bahwa semacam itu terlalu menggampangkan dan memfantasikan pengalaman budaya Islam yang suci, sebagai pembanding, tulisan ini mengembalikan pemahaman yang rinci tentang ḥarīm dan mendefinisikan implikasi islami yang lebih luas dari konsep ḥarīm di dalam budaya Arab. Dengan menerapkan etimologi dan kitab suci Islam untuk mempelajari desain arsitektur, penelitian ini mengeksplorasi sentralitas konsep hijāb (jilbab) ke organisasi ruang fisik bagi wanita di rumah islami. Ditulis dari perspektif seorang wanita Muslim Arab, studi ini berusaha untuk mengeksplorasi konsep harīm dari perspektif "Lainnya".
\end{abstract}

Kata kunci: Wanita Muslim, Orientalis, penjelajah Barat, ḥarīm, budaya Arab

\section{Introduction: The Etymology of Harīm and Women}

In Arabic, the word harīm (حريج) means women, and hurma (حرمد), the singular, means woman. All such words derive from the verb haram (حرد), which means prohibited. Harīm is a well-known term beyond the Arab world and popular among Western travellers as well. It is also presented through travel narratives as a space of non-freedom, evil, and idleness ${ }^{1}$, simply as a world of fantasy packed with women who are always kept indoors. In 1915 Elizabeth Cooper states that:

The word harim is much misunderstood by the people of the Western world. The Arabic word harim simply means the women's quarters while the harīm-like are the apartments reserved for the female members and children of the family. The literal meaning is exclusiveness, seclusion, privacy. In its restricted sense it embodies the two meaning of the women of the household and their exclusive apartments. ${ }^{2}$

For the West, the image of the harim remains a delightfully shocking one of polygamy and sequestration as Reina Lewis claims ${ }^{3}$, whereas, Alev Lytle Croutier states that harīm, as a space, is the separate, protected part of a household where women, children and servants live in maximum seclusion and privacy ${ }^{4}$. Most importantly, hurma (حرما) means a woman and literally means sacredness. Hurma and its cognate haram (حر) is a customary way of making respectful reference to a man's wife. She and the women in the house are the foremost repository of the house's hurma (sanctity, sanctuary). Haram and hurma are still used in Arabic, among middle and upper classes, as a respectful form of address to a married woman. 
Haram (حرد), then, means sacred, and the sanctuaries of Islamic cities Makkah and Madinah are, appropriately, called Al-Haram Al-Sharif. Harīm is another noun derived from the same verb, which means prohibited, forbidden and punishable, from a religious point of view. Additionally, ihram is another derived term that implies a state in which one is prohibited to practice certain deeds that are lawful at other times. The Muslim pilgrimages of umra $^{5}$ and Hajj are performed during such a state, and special clothes need to be worn to participate in such events. Mahram is also derived from the verb haram; it means a person whom a woman cannot marry due to the close familial relationship (blood relatives such as a father, a brother, etc. $)^{6}$ or refers to her own husband as a mahram. The mahram ought to travel with the woman for her protection and so she will not to be alone.

All of these terms - and many more derived from the same verb haram - embody the concepts of sacredness, protection and respect, as well as religious restrictions and rules to be performed and acknowledged. In the Muslim world, houses are the most respected of places and have their own hurma. This includes the houses of Allah (masjid), the Prophet's house in Madinah and ordinary houses. Sacredness is the common factor, indicating ownership and privacy, restricted access and the observance of rules. Rules govern the houses of Allah, especially in Makkah and Madinah where non-Muslims cannot enter. However, the Prophet's house has its own rules for access, which are discussed in detail in the Qur'an. Similarly, ordinary houses are respected as territories belonging to their occupants who also have the right to set their own rules within the boundaries of Islam.

Overall, women are the main consideration in the broader concept of the harīm. The term hurma (woman), embodying the literal meaning of sacredness, obliges the drawing of a screen or a curtain in order to convey respect. Privacy is insisted upon as a means of protecting the Hurma and its several dimensions, the Hurma of the masjid, the Hurma of the tomb and mainly the hurma of the house and its households. Therefore, the concept of the Hurma and the presence of harīm (women) play a crucial part in the hijāa $b^{7}$ (concealing and veiling) and the harīm as an interior space. The most common use of the word harīm is to denote the space in the family home reserved for women, suggesting a clear idea of segregation. The harīm, as a space, is a zone within the house that is governed by the concept of the hijāb, once more for the harīm (women) as the main occupiers. harīm, from Arabic, is an architectural term used to define a space utilised by women and the family of the house. Haremlik, as a Turkish term, commonly referred to the same space, during the Ottoman period ${ }^{8}$. Regardless of the different words used to describe the same space, both harim or haremlik were disseminated by Western travellers. In fact, harīm is not just an enclosed space for women; it is a name for a group of women or any area which has been occupied by women without any physical boundaries. Literally, it is a defined place for a specific gender, but it does not have to be an enclosed space.

In Hindi, harīm derives from the Arabic haram, whereas harīm is applied to the women of the family and their apartments. This word is not now commonly used in India; zenana is the current word for the same description, and it is used in English literature during the 1700s to describe women's sections in palaces ${ }^{9}$. Zenana, from Farsi zanana, is derived from zan, that is, 'women'; and designates the apartments of a house in which the women of the family are secluded. This Islamic rule of female seclusion has been largely adopted by the Hindus of Bengal and by the Mahrattas. Zanana is also the term used for the women of the family themselves ${ }^{10}$. Zanana is a Mughal term used to describe the women's quarters in a palace or house ${ }^{11}$. It is also written as zenana, which means the same as harem ${ }^{12}$. Considering the Persian cultural impact on the Islamic Mughal, this term is used to describe segregation which is evident in whichever language is used among Muslims. That is, both terms harīm and zanana mean women and are used to describe women's quarters. Zenane is commonly used in the Sind (southern Pakistan) and in the Indian subcontinent, where strict rule of purdah (hijāb) is applied, and thus develops gender segregation ${ }^{13,14}$.

Partha Mitter warns against the misuse of old terms, as he states, “The zanana (women's quarters), misleadingly called the Jahangiri Mahall, impressed us with its red sandstone and marble work and deeply carved surfaces" ${ }^{15}$. An example might be the use of the term zenana to describe the lattice wooden projected window in the upper floor of the Arab Hall in London, by Daniel Robbins, the curator of Leighton House ${ }^{16}$. Although Robbins claims that the origin of the lattice window is from Cairo, he refers to an Indian term which has the same meaning of the screened and secluded place for women. This misleading usage of terms changes the fact that this window was actually brought from the Middle East, Cairo in particular, and not from India. This paper argues that the misuse of subtle but etymologically important cultural descriptors guarantees the disappearance of authentic Islamic and Arabic terms and lessens their impact on other cultures.

Zenana is used in Persia and Turkey; however, in India the notion of being behind a screen can be expressed by saying: 'She is purdah-nashim, or simply purdah.' The purdah is the screen that shuts the woman away from the outside world. A similar expression with a similar meaning is used in Egypt: 
'Yes, my daughters go to school' a mother will say, 'but they are kept harīm,17. In Hindi, purdah or parda is a term from Persian 'parda', meaning a 'curtain', especially a curtain screening women from being seen by men. A woman of position who observes such rules of seclusion is termed pardanishin, or 'one who sits behind a curtain' ${ }^{18}$. The term in Hindi and Farsi has an interwoven and a metaphorical meaning: a curtain, hanging, screen, partition or blind. It also means veil, lid (of the eye), thin covering, layer, veneer, film, seclusion (especially of a Muslim woman) and privacy ${ }^{19}$. Purda is also known as an area for women which is screened from the sight of men by a curtain ${ }^{20}$. In Arabic, purd or purda means a black square narrow dress $^{21}$, or a garment with strips for wrapping or clothing the body ${ }^{22}$. In Persia, enderun or zenane reflects the exact concept of a secluded space within the house $\mathrm{e}^{23,24}$. This reflects the metaphorical concept of the hijāb as it is written in the Qur'an: 'behind a screen'. However, the physical form of this concept can be seen in the construction of the Islamic house layout that focuses on gender segregation.

As a term, the hijāb is known in the Arab and the Islamic world alike; however, in some regions local terminology substitutes the Arabic term while the concept remains the same. Accordingly, hijāb is not restricted to the house, where segregation is needed, but it can be seen everywhere. Once a screen is draped, the sense of women's presence is evident and substantial. Anywhere in the Islamic world, even today, it is easily spotted. The hijāb (screen) follows women wherever they go as a shield for protection, more for privacy, and to enable to move with ease and comfort without coming to harm. The dual meaning of the term harīm, encompasses both a space and its occupants, and is parallel to the connection existing between women and the hijāb as a concept. Although the harīm as a space is mainly for the family and the women of the house, it has been constantly claimed as a world of fantasy, as Cooper puts it:

One hears the word harīm and instantly conjures up Arabian Nights scenes of rare hangings, subdued lights, and beautiful odalisques lounging on soft divans, slaves, incense, and a general air of sensuousness pervading the entire place. ${ }^{25}$

In conclusion, the conflation of the terms and forms of the hijāb and the harīm is evidently a misrepresentation by the 19th century Orientalists, as it is reflected in this paper argument. Considering that the Orientalist is a term used for someone who is knowledgeable about the Orient, its people, languages, history, customs, religion and literature. It also applies to Western painters of the Oriental world of the 19th century who used Eastern themes in their works ${ }^{26}$.

\section{The Hijāb within the harīm}

Graham-Brown in 1988 stated that:

The majority of westerners [...] took little account of social nuances in practice of veiling. They were simply fascinated or shocked by the sight of veiled women in city streets, visible yet invisible. For western men in particular, the veil presented a challenge to the imagination. Writers, artists and photographers dwelt on the 'mysteries' which lay behind this piece of cloth. ${ }^{27}$

The fantasy and mystery surrounding veiled women extends to involve the harīm quarter, which is intensively used as an arena for imagining and staging Arabian Nights characters by the Orientalists. Despite these imaginative interpretations, some images link the hijāb to women, in instance where a screen, veiled women and a guard would have been a common scene in the Islamic world. Jean-Lean Gerome depicted these elements when women are outside as in Harem in the Kiosk, 1875-80 (Figure 1), and in the Harem Outing, 1869 (Figure 2). Such paintings reflect the double sense of the hijāb of women as a veil and a space and the connection between both, in reality and in the mind of the artists alike.

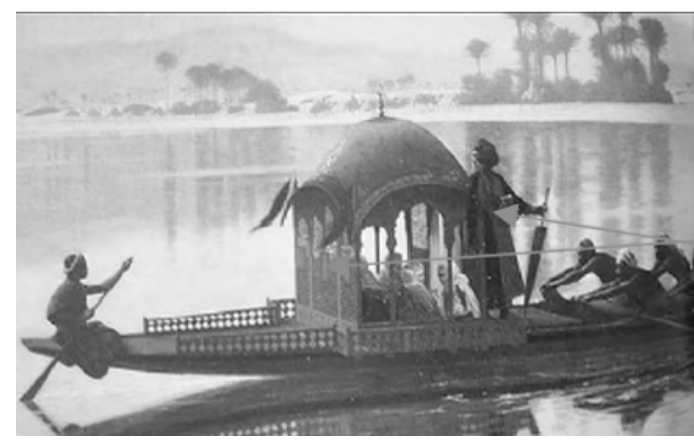

Figure 1. Harem in the Kiosk, 1875-80. Jean Lean Gerome, Oil on canvas, $76.2 \times 111.7 \mathrm{~cm}$. The Najd Collection. (Source: Benjamin, 103)

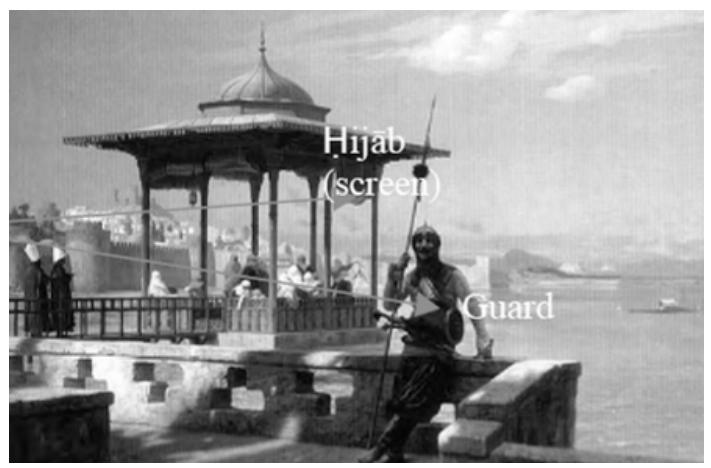

Figure 2. Harem Outing, 1869. Jean-Lean Gérôme. Oil on canvas, $120 \times 178 \mathrm{~cm}$. Chrysler Museum of Art, Norfolk, Virginia. (Source: Lemaires, 239-241) 
Orientalists' projection and imagination have resulted in the distribution of enormous quantities of representations of the hijāb in clothing and architecture outside the Islamic world. The widespread consumption of these images in the West suggests that the 'East' existed solely for the pleasure of the Orientalists, and that they might invent it as they saw fit. The seclusion of the harīm has always been a challenge for travellers who lack the understanding of Islamic culture. This misapprehension applies to female and male travellers alike. Thus, images from inside the house show the harīm and women in unrealistic scenes. The harīm and its lattice wooden window become a stage for the Orientalists imagination and fantasy, a stage for their daydreams of their own version and interpretation of the Arabian Nights ${ }^{28}$. Such scenes are to be seen in Eugène Giraud's paintings: Interior of an Egyptian Harem, n.d. (Figure 3) and Lord of the Harem, n.d.

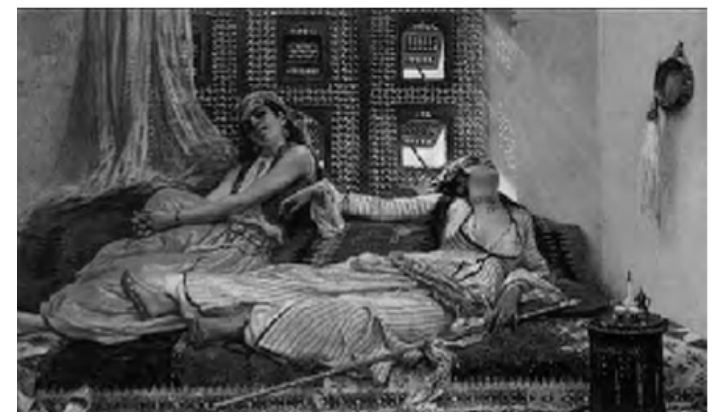

Figure 3. Interior of an Egyptian Harem. Eugene Giraud. (Source: Thornton, Women, 28)

The image distributed was of the oppression and incarceration of 'Eastern' women and the harīm as a space of non-freedom, idleness and evil ${ }^{29}$. The veiled harīm (women) captivates both the sight and the imagination, as does the harīm, as a space for segregation which conceals the inner of the house. Instead of the hijāb principle being demonstrated as a major core of the harīm, it is wrongly exposed, rather than concealed, and the hurma of this sacred place is thus aggressively broken and neglected. Meyda Yegenoglu agrees that it is this trope of concealment which led many male travellers in the 19th century to denounce the "hateful" mystery of the harīm and the veil. However, despite this overrepresentation, the Orientalist's desire is always left unsatisfied. In fact the hurma of this sacred place ensures that the space of the Oriental woman is not only "hermetically sealed," in Yegenoglu's words, that is, preventing actual observation, but also that the inhabitant of the harem is resistant to give any information regarding this "inner" space ${ }^{30}$.

\section{The Experience of the harīm}

Alev Lytle Croutier, who experienced being within a secluded harīm in Turkey during the early $19^{\text {th }}$ century, said 'Our private lives must be walled' $^{31}$. This refers to a Turkish proverb that is also common in Arabic, as well as Islamic cultures. Women's lives, their private lives in particular, must be 'walled in' by every means. This includes segregation within the house, as hijāb is another form of being walled in, to keep their beauty intact. It is believed, in Islam, that women are like jewels needing to be treasured and hidden away from others' sight and away from strangers. This aspect has long been practiced within the Islamic house across the Islamic world, for example, Mary Walker ${ }^{32}$, a female artist who depicted women in their harīm in Turkey in the 1880 s, stressed that the central priority for the harim women was to conceal any portrayals of themselves. She noted that in the harīm of Sultana Zeineb ${ }^{33}$, the daughter of Muhammad Ali Pasha, the large three-quarter-length image of Zeineb was hung in the sitting room of her summer palace on the Bosphorus; but it was veiled by a curtain of white silk. The restricted visibility of the portrait reflects the Islamic necessity for the veil to protect even representations of females from the gaze of the male workers of the house ${ }^{34}$. If this was the case in Turkey, a Muslim counterpart in other parts of the Islamic world acted similarly, as Elizabeth Cooper quoted a Muslim woman in Hyderabad, India in the 1900s:

She laughed apologetically and said: "I know what you think, but I cannot sit here with any degree of comfort if I think someone, a servant or any one of my husband's guests, might pass by. It is instinct; my mother and my mother's mother were 'purdah' women, and it is in the blood." 35

The speaker was about to sit in a room when she noticed that one of the blinds of the window was open. Despite the fact that the windows opened onto a garden, she wanted to ensure that the windows were securely closed so that no one could look into the room. This example shows that the physical practice of the hijāb is performed in India and throughout the Islamic world. It is in the blood; it is exactly as described above ${ }^{36}$.

\section{The Harìm in the Islamic House}

The aim of the Islamic house is to fulfill the Islamic rule of the hijāb, where the veil is drawn to clad façades, and zones are secluded to achieve privacy. That is, the lattice wooden projected windows as screens and the harīm as segregation quarters are forms of the hijāb. The most fascinating connections 
between the hijāb, women and textiles are drawn by Western travellers in the nineteenth and early twentieth centuries. There is an evident role for fabric and textiles in Islamic cities, which perform many functions both indoors and outdoors. The significant use of textiles is still obvious today in Muslim societies, especially during ceremonies.

Hijāb within the house is identified with segregation and not just screening. Segregation in zones within the house, regardless of the varieties in terms of the Islamic regions, also fulfils the hijāb concept. However, screening can be seen in the entrance hall when a curtain is hung to break any direct view from the outside. This rule is observed in Islamic domestic architecture, since no direct view or entrance openings are allowed. A barrier is always provided to screen the inner house from direct view. This could be a wall, a curtain or even a courtyard. The guarding of the Caliph's entrance and the women's quarters shows a similar situation as in Entering the Harem, 1870s (Figure 4). Under Islamic moral codes a man, even the master of the house, should make some noise when he enters the house, as there may be female visitors or neighbours in the vicinity. Therefore, to avoid any awkward situations arising within the home, upon entering a room a respectful and considerate man should make some kind of noise (a cough or even a formal announcement of his intention to enter) to alert the women inside of his presence and imminent entrance.

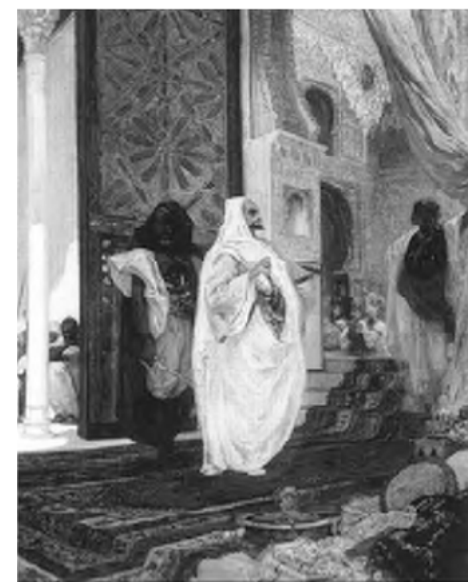

Figure 4. Entering the Harem, 1870s. Georges Clairin. Oil on canvas $82 \times 65 \mathrm{~cm}$. The Walter Art Gallery, Baltimore, Maryland. (Source: Benjamin, 123)

The need for the hijāab, as a means of secluding men and women in Islamic societies, is a phenomenon that is applied according to the circumstances of each region. This is one of the strengths of Islamic architecture, where flexibility in crafts and materials considers the climate, and leaves room for creativity and identity when designing buildings similar to the variety of ways in which women conceal themselves across the Islamic world. The unity of the application of the Islamic law is reflected within the Islamic house. The practice of the hijāb inside the house is discussed in detail in the Qur'an and the Sunnah, including the obligation of asking for permission before entering. The Qur'an governs every aspect in Muslims' daily life, and defines Islamic etiquette inside the house. Obeying the rules of the hijāb as a garment reflects the concealment of women's physiques when they go out of the house. Similarly, architectural hijāb, such as screens and harīm quarters, demonstrate concealment within the house. This architectural concealment gives women their own freedom and privacy, as they cannot remain veiled outside and inside. The house is a women's haven, as they are the main occupants.

This notion of privacy is a wider Islamic concern; the geographical spread of the application of the hijāb ranges beyond the Arab world. The presence of women plays an important role in the design of Islamic houses. This results in plans where privacy can be enhanced and gender identity preserved, where each sex can be at ease in each one's world. Gender identity is still a significant feature in some regions of the Islamic world. Privacy is one facet of this hurma, which includes inhabitants' respect of each other's needs and prevents intrusions, but not for the sake of individuals. On the contrary, Lloyd Llewellyn-Jones claim that 'privacy' as a noun does not exist in Latin, and did not come into common use until the sixteenth century, and that the concept remained ambiguous until the $1890 \mathrm{~s}^{37,38}$.

The sense of privacy within the Islamic house is important, and it is noticeable even from the façade. Homes in most Islamic cities have blank walls facing the street, or have lattice windows and screens from which the inhabitants can look out into the street without being seen. For travellers, these walls and screens appear as definitive boundaries between the public and the private sphere, and reinforce the notion that this boundary marks off the domain of women ${ }^{39,40}$. There is very often a lack of awareness and understanding when discussing the link between Islam and domestic life. The practice of the Muslim daily life is interwoven within religion. Islam is absorbed and administrated as part of the daily routine. Observing and studying aspects of Muslim daily life, including architecture and inhabitation, cannot be excluded from Islam as the dominating factor. In dealing with domestic life where the harīm plays a part of activity within the house, the same is true.

However, the religious practice within the Muslim domestic space has been neglected in Orientalists' descriptions and representations. Edward William Lane (1801-1876), who first travelled to 
Cairo in 1825 and stayed for three years, either overlooked this issue and reduced it to the status of superstition, or pushed it to one side to leave room for negative remarks. Consequently, what is written in relation to domestic daily life practices, including the harīm inhabitation, was taken for granted and generalised as the stereotype. This produced a biased conclusion that reverberated even more strongly in works produced by Orientalist scholars after EW. Lane, such as in the work of Lane's great grand-nephew Stanley Lane-Poole who took what his great grandfather wrote for granted ${ }^{41}$. This Orientalist bias was not only evident during Stanley LanePoole's time (1854-1931). Mark Crinson, writing in 1996 also claims that Lane's book, An Account of the Manners and Customs of the Modern Egyptians, can be used as an authoritative reference work of Islamic architecture $^{42}$. Perhaps this is the key reason why Lane insisted on going 'native' in describing the domestic daily life in Cairo.

\section{John Frederick Lewis and the Experience of the Harīm}

Lewis was the first, and for many years the only, British artist to spend an extended period in the Near East as a resident. From 1841 to 1851, he lived in one of the old Cairo houses, as he went completely native, he appears to have made a deliberate effort to loosen the ties of his culture. He has a little contact with his compatriots, despite the presence of many English tourists in Cairo in the 1840s. Only a few English visitors allow glimpses of Lewis's life in Cairo. His numerous sketches, some inscribed and dated, indicate some of his activities, the rest must remain speculation based on what is known of Cairene society in the midnineteenth century. ${ }^{43}$

While Briony Llewellyn's claim focuses on the assumption that JF. Lewis went completely 'native' or had little contact with his peers, other evidence indicates the opposite. In fact, JF. Lewis attended the British Consul dinner in 1842, as claimed by Sir Thomas Phillips who reportedly met JF. Lewis there. Llewellyn herself states that Colonel Burnett recorded this at the time in a letter to his brother. In the same year, James Wild, the Orientalist and British architect, visited JF. Lewis in his house. In addition, JF. Lewis was host to various friends, including William Makepeace Thackeray in $1844^{44}$. John Elphinstone, the governor of Madras, who was a friend of JF. Lewis's brother, FC. Lewis, also visited JF. Lewis in 1845 and noted that JF. Lewis was living in the most Ottoman quarter. Most importantly, JF. Lewis met Marian Harper - a British woman - and married her in 1847. Therefore, he was not as cut off from other Orientalists as it is sometimes claimed. Such a claim may well have been manufactured to persuade readers 'back home' about the authenticity of J. F. Lewis's experiences and observations.
JF. Lewis lived in Cairo as a Turkish Bey (chieftain), and his way of living and appearance may have given the impression of him being treated like a Bey. He could well have entered masjid (mosques) under this disguise with the authorities' protection, as his painting of Interior of Mosque or Afternoon Prayer (n.d.) suggests. JF. Lewis was accepted by Cairene society, and his way of life allowed him to sketch people and scenes without hindrance ${ }^{45}$. It is notable that JF. Lewis chose to live as a noble Bey among Turkish Beys and the upper classes, and not as an ordinary local person as Lane did. Such experience reflects another slice of the Cairene fabric of life, and the harīm s of the Mamluk house in particular.

\section{The Artist's House}

J. F. Lewis lived in a Mamluk-style house situated in the Ezbekiya ${ }^{46}$ quarter in Cairo, not far from Masjid Sultan Hassan and Bab el-luq. The area contained the palaces of Ibrahim and Abbas Pasha, some of the finest buildings in this quarter, as well as the new Hotel d'Orient. Therefore, the area was full of palaces of ruling emirs and merchants' houses, even before Napoleon's expedition in 1798. Living in this quarter indicates that the house was not one typical of local people, but of wealthy inhabitants. In fact, the house is believed to have originally belonged to Kiani [Qiani] $\mathrm{Bey}^{47}$ from the Mamluk period (1250-1517). This gives an indication of the history of the house. Knowing this fact is a crucial factor in documenting the history of the harīm and its existence in the Mamluk time, as Miles Danby indicates:

Under the Mamlouks, the domestic architecture of the growing merchant class was to reach a high degree of sophistication and the Mamlouk house was to remain the standard type in Cairo until the late nineteenth century, in spite of Ottoman rule and influence. The typical two or three-storey courtyard house was developed to accommodate the extended family and the business needs of the merchant. These interiors were later to fascinate European visitors, especially those who spent a long period living in Cairo. In the early nineteenth century EW. Lane described in graphic prose the houses and the way of life in the urban middle class. Similarly, the painter Frederick Lewis depicted the luxurious interiors and streetscapes of Cairo, in glowing watercolours and oils. Interior scenes of families, with graceful ladies reclining on rich coloured textiles before alcoves lit through elaborate mashrabiyya windows, attracted enthusiastic crowds when they were exhibited in the $1850 \mathrm{~s}$ at the Old Watercolour Society in London. ${ }^{48}$

JF. Lewis's house played a major role in most of his paintings; several of his works evoke its interior court and its large rooms decorated with the trellis-like wood screens. The house has also been depicted in images by James Wild and in text by Thackeray. Wild drew some interiors in JF. Lewis's house; the mandarah and the bath of the house were 
among the collection of Wild's depiction of Cairo in 1842 (Crinson, 101-103) $^{49}$. However, Thackeray describes his experience of being in this recessed room thus:

He conducted me into a great hall, where there was a great, large Saracenic oriel window. He seated me on a divan ... Opposite the divan is a great bay window, with a divan likewise round the niche. It looks out upon a garden about the size of Fountain-court, Temple; surrounded by the tall houses of the quarter. The garden is full of green. A great palm-tree springs up the midst, with plentiful shrubberies, and a talking fountain ... 50

$\mathrm{JF}$. Lewis depicted the same scene shown in The Recess in a Chamber of the Painter's House in Cairo, in the 1840s (Figure 5). This chamber scene that Thackeray also described is inscribed as 'Mandarah of my house at Cairo' of 1840-51. This study is believed to be developed into another painting 'The Reception' in 1873. Although the painting of this chamber is believed to be a study of JF. Lewis's own house in Cairo, the painting could also be seen as an amalgam of the studies of Cairene domestic interiors. The house could be the same house which was later occupied by another British resident in Cairo, Mr Lockwood. It was visited and drawn by Thomas Seddon $^{51}$ in 1854 as Interior of the Deewan ${ }^{52}$.

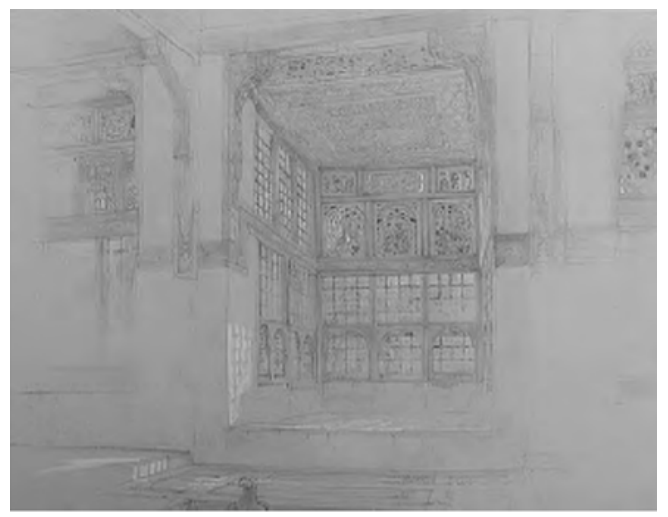

Figure 5. The Recess in a Chamber of the Painter's House in Cairo. 1840s. (Source: Victoria \& Albert Museum, prints room)

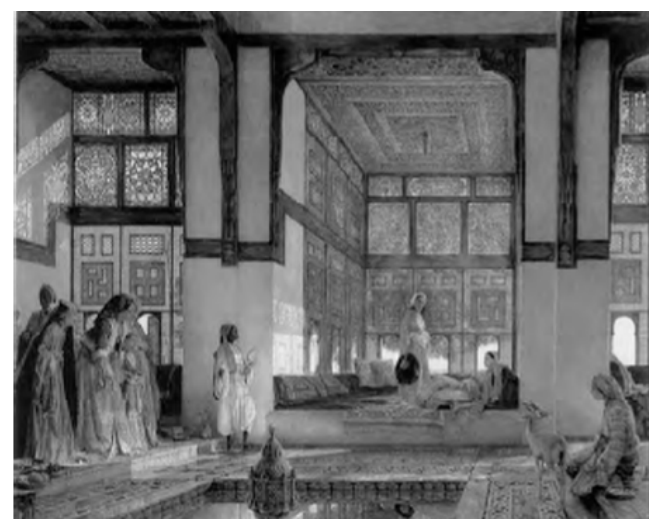

Figure 6. The Reception, JF. Lewis, 1873. (Source: Danby, 66)

\section{The Reading of the Harim in Lewis's Paintings}

This analysis focuses on the hijāb as the main function of the harīm, therefore this criterion will be used to examine whether these scenes behind lattice screens are authentic and could be seen in Muslim cultures. JF. Lewis's paintings of the harīm seem imaginary, and give the idea of the artist's speculation of what was behind these screens. JF. Lewis may understand some of the main concepts of Islamic society, regarding the hijāb and segregation between genders in relation to the Islamic architecture. This may justify his tendency to link the wooden screens with the harīm or family sections in most of his paintings. He imagined the pattern of inhabitation of the harīm as he could have experienced it himself. For instance, the first domestic scene of the harīm was captured in detail in 1849. Although The Hareem is inspired by JF. Lewis's house in Cairo, the setting is repeated in many of JF. Lewis's imaginary harīm.

JF. Lewis was interested in sketching Islamic architecture and studying the impact of light and shadow; but after his marriage, he added figures to this architectural background. It would have been difficult to draw people in action outside, as living in an Arab quarter with the aim of building trust with native people would have made it difficult to get models to pose. JF. Lewis may have understood women's status in Islamic culture and modelled his household to play this role instead.

The two important paintings in JF. Lewis's collection that reflect the sense of the harīm are The Hareem and The Reception, the former is sometimes spelled in some references The Hhareem $^{53}$. Lewis may try to write the correct spelling of the harīm, as the first letter ' $\tau$ ' cannot

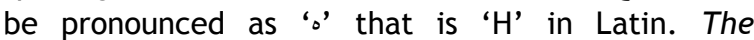
Hhareem was the first painting executed in Cairo in 1849-50 (Figure 7), however; there are at least four major harīm paintings ${ }^{54}$. Perhaps JF. Lewis relied on the account of harīm visits by women travellers or by stories he could have been told by his wife who, as a woman, might have visited harīm sections in Cairo. JF. Lewis often used his wife as a model for his harīm paintings and may well have done so in this instance ${ }^{55}$. The harīm as a space is depicted to narrate different stories of inhabitation behind screens. The story of The Hhareem of 1849 is believed to have been written by the artist himself, as the spectacle of an Abyssinian slave being introduced into the harīm of a MamlUk Bey ${ }^{56}$. The scene gives the viewer some idea of the cultural hierarchy contained in JF. Lewis's paintings, as he assumes the character of a Turkish Bey with his wife or wives, children, a slave and a servant. JF. Lewis may have come across stories or was perhaps aware of gossip about Pashas and Beys, and he tried to put these stories onto canvas for exhibition back home. 
Staging these stories from the harīm reflects the painter's stay in Cairo, especially as he does not maintain any form of written documentation. His sketches and paintings reflect what he experienced there - or wished to. Therefore these stories of the harīm reflect his interpretation of his own experience of being in a Mamluk house, living as a Bey.

Another JF. Lewis painting of the harīm, which is believed to be a fragment of the previous one, is in the Victoria \& Albert Museum (see Figure 8). It is similar to a portion of the original painting of The Hareem $^{57}$. The same scene is depicted, for the third time, in oil with a different message to that of 1849. An Intercepted Correspondence, 1869 (Figure 9) has almost the same setting as The Hareem, with some other architectural details of the room in a wider perspective, though the Bey is older. The Study of the Hareem (Figure 10) is more like an incomplete watercolour painting or a sketch. This coloured sketch is now in Australia, and is believed to date from 1850. The finished painting, of almost the same scene of the study, is in the Birmingham Museum, called The Hareem ${ }^{58}$, and is undated (Figure 11). However, the painting seems to be the reverse of the previous one of The Hhareem, unless it is the other side of the same room in J. F. Lewis's house. The scene shows the entrance of the room, which could be another part of the artist's house. This portion of the painting is also depicted in many of $\mathrm{J}$. F. Lewis's paintings.

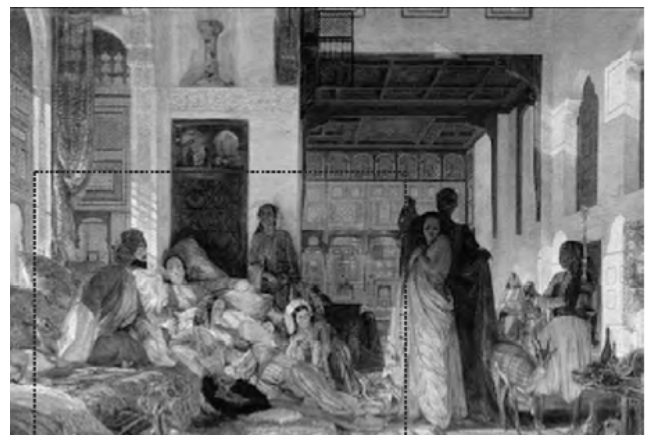

Figure 7. The Hareem, Cairo. 1849. (Source: Benjamin, 79)

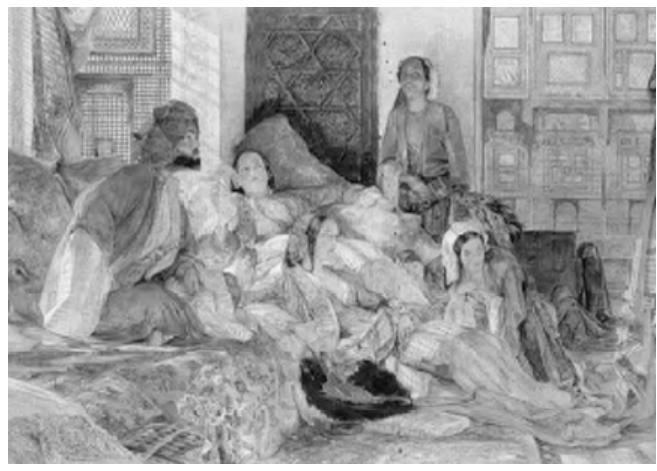

Figure 8. The Hareem 1850, the fragment version in the Victoria \& Albert Museum. (Source: Benjamin, 81)
By comparing the sketch and the painting of the harīm and its study, some different details can be identified. The final painting is in oil, which means that the painting could have been executed sometime after 1858, when the painter changed from watercolour medium to oil. The proportion of some of the architectural elements varies in the sketch; for example, the wall beside the wardrobe works as a background for the standing woman and as a space before the entrance arch. More importantly, the scene demonstrates that the lattice wooden window within the harīm is big enough to accommodate a group of women within. Through the arch there is another view of the lattice window from the front. This painting, and the other of the harim shows that the house is full of these lattice windows which are depicted from different views, at close range and at a distance. These paintings are clear indications of J. F. Lewis's passion for these wooden screens and their impact on the interior both architecturally and socially. Doubtless, such screens are indications of the importance role of the hijāb in the Islamic house, and in the harīm in particular.

Another small detail, which is rarely seen in domestic scenes in the Islamic world, is of a dog lying down in the same seating area as the inhabitants. So that the place could be kept clean and ready for people to perform their prayers anywhere, dogs have never been kept inside the house $^{59}$. The depiction of the dog indoors is an entirely different issue for J. F. Lewis as an animal lover. It seems that he did not consider the Islamic perspective before depicting this harīm scene; or he included a dog in order to please the public, in this case, the Victorian viewers. In this harīm painting, and in the first painting of 1849 , there is a curtain which could be interpreted in a similar way to the use of curtains with the lattice window in Cairo. The curtain in this scene is light and translucent in comparison to the heavy one in the first harīm painting.

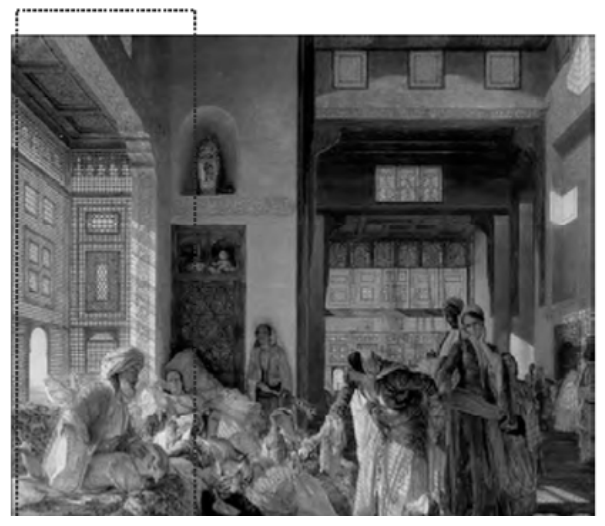

Figure 9. An Intercepted Correspondence, 1869. (Source: Thornton, Women, 131) 
Jennifer Scarce claims that the wealthy people in Cairo furnished their homes with handsome textiles, but that the use of carved wooden lattice screens across the wide and deep windows left no space for velvet and brocaded silk hangings and curtains, which would have been too thick and heavy for the climate of Cairo ${ }^{60}$. Sophia Lane-Poole, on the contrary, describes windows furnished with muslin curtains in white with coloured fringes, including some pinks and blue in one of the Pasha's harīm, but she describes no curtains in the house which the Lanes occupied ${ }^{61}$. Curtains may have been used to obscure figures, to prevent dust, or to weaken direct light and, more importantly, for the purposes of this argument, to provide privacy. But in the case of JF. Lewis's painting, they probably would have represented luxury. In fact, JF. Lewis depicts these kinds of screens with curtains in another painting, Life in the harīm, Cairo, 1858 (Figure 13). This could be an indication of the status of the inhabitants, and in this might be included JF. Lewis's house in Cairo as an example of wealthy housing.

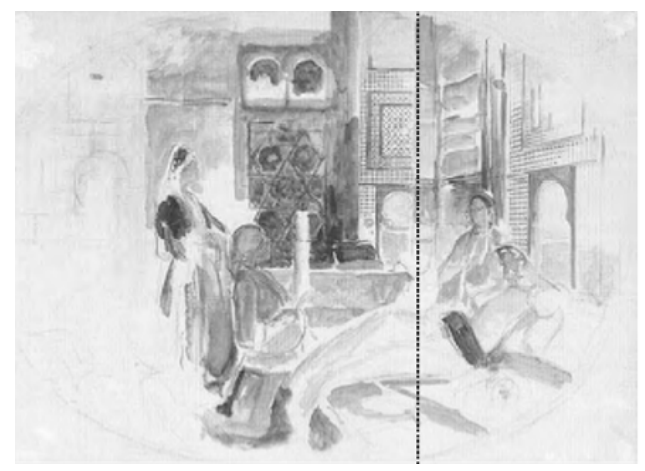

Figure 10. Study of the Hareem, Cairo. 1850. (Source: Benjamin, 82)

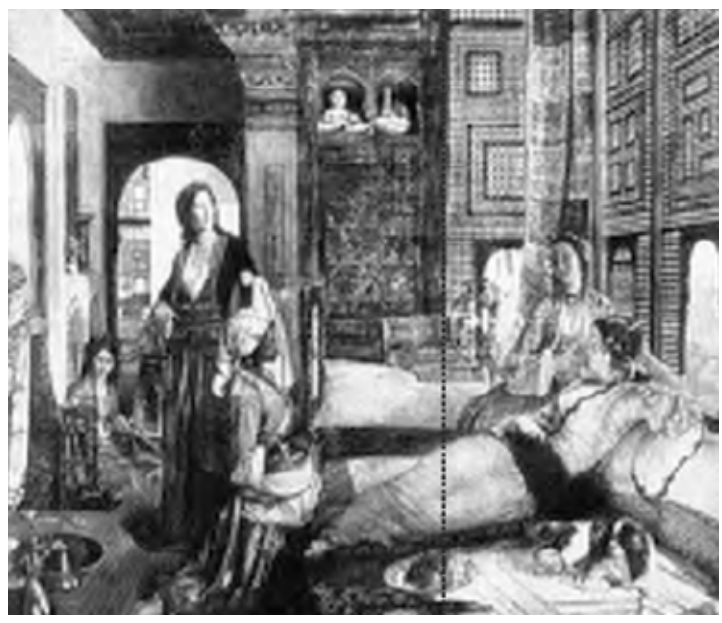

Figure 11. The Hareem, Cairo. n.d. (Souce: Benjamin, 82)

The Reception was executed in 1873 (Figure 6), a decade after JF. Lewis's return to England. The painting is mainly based on Mandarah of my House at
Cairo 1840-51, a sketch of his house, together with studio props, costumes, vases and other objects. The setting of the painting, the architectural atmosphere and its furniture, could be the one described by Thackeray in his visit. However, the proportions seem different, or, at least, the view of the perspective in the painting is different to that of the sketch. The massive lattice window in the mandarah is claimed to be a depiction of a visit of ladies from another harīm ${ }^{62,63}$. Danby claims that the screened windows are painted with meticulous accuracy, showing diffused light from the lower turned wood sections compared with clear-cut shadows from the coloured glass patterns set in the higher panels ${ }^{64}$. What is certain in this painting is JF. Lewis's admiration for the geometric and organic designs of his Cairene house and their ability to subordinate the human figures on canvas as Yeazell asserts ${ }^{65}$. Doubtless, the admiration of the harīm and the hijāb concepts is well depicted and highly captivated by Western travellers.

Llewellyn claims that the setting and the costumes of The Reception are authentic, where JF. Lewis depicts women not in the upper rooms of the house but in the mandarah or men's reception. The scene resembles an everyday occurrence in Cairo, which could parallel an ordinary Victorian one ${ }^{66}$. The mandarah could be used by women in the absence of the men of the house and their visitors. However, the use of extra screens for the opening of the projected lattice windows or curtains in this area would be essential, in order for women to be secured and secluded. Such a setting, with its lack of privacy for women, raises questions of authenticity. In the harīm, as a women's section, privacy is strictly required, but the scene does not reflect this necessity. In fact, the lattice screens in most of JF. Lewis's scenes remain open, and the outside scenery is clear from the inside. Although JF. Lewis paints a curtain to indicate screening, the setting is not authentic in this sense. In these paintings the artist demonstrates the link between the inside and the outside through the lattice window and how the occupier can experience this notion. He sometimes succeeds in giving the impression of the lattice screen as a link between the inner house and the outer space; but not when it comes to the lattice window as a screen and a hijāb device.

The area within the recess window illustrates the sitting area and the interior furnishing. In JF. Lewis's scenes, the seating area and furniture of the harīm is depicted with features of an Arabic interior. Either high or low seating is common in a lattice projected window; both styles are furnished with mattresses and side cushions covered with white lace. JF. Lewis depicts similar seating in Life of the harīm, Constantinople, in 1857 (Figure 12), and again in Oriental Interior (n.d.). This seating 
arrangement was used in Cairo and in Constantinople (Turkey); it is still used there today, and in some other parts of the Arab world. This style of seating has been used in the Arab world and has been distributed throughout the Islamic world; it is known, mistakenly, as 'divan'. The style of arranging mattresses and back or side cushions and the way of clothing them is called 'Jalsa Arabi' or Arabic seating. The Jalsa may be adjacent to a lattice window, or may just surround the room on three sides, as shown in Oriental Interior and some Orientalists' paintings. Lady Montagu also described this style in Turkey, in 1717:

[t]he rooms are all spread with Persian carpets, and raised at one end (my chamber is raised at both ends) about two feet. This is the sofa, and is laid with a richer sort of carpet, and all around it a sort of couch, raised half a foot, covered with rich silk according to the fancy or magnificence of the owner. Mine is of scarlet cloth, with a gold fringe; round this are placed, standing against the wall, two rows of cushions, the first very large, and the next little ones; ... They are generally brocade, or embroidery of gold wire upon white satin:- nothing can look more gay and splendid. These seats are so convenient and easy, I shall never endure chairs as long as I live. ${ }^{67}$

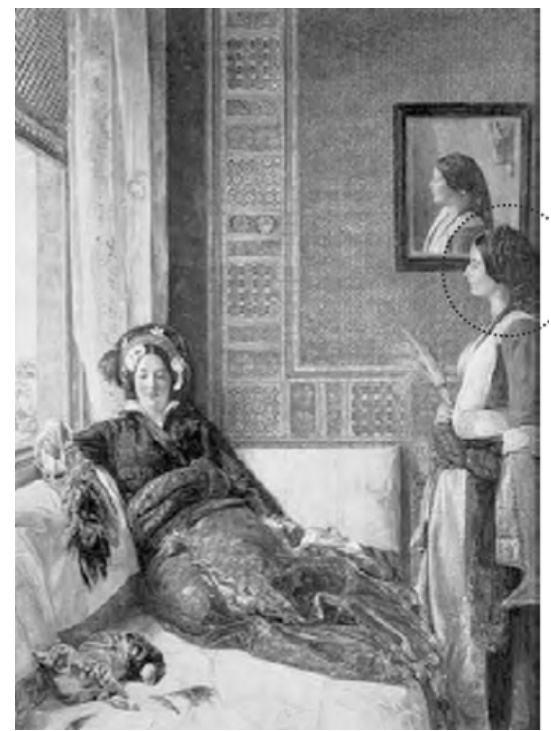

Figure 12. Ḥarīm Life in Constantinople, 1857

The high seating, or the inner $d a k k a^{68}$ covered with the same cloth as the mattress and the cushions, can be seen in most of the artist's paintings. The floral golden fabric is also repeated in most, if not all, of JF. Lewis's work, especially his earliest harīm scenes, such as Life in the harīm, Cairo of 1858 (Figure 13). This fabric is likely to be authentic, as JF. Lewis may have brought it home with the other artefacts that he imported from Cairo. The same fabric is repeated in Hareem Life, Constantinople, which Elizabeth Malcolm describes as follows: "the sofa itself is a golden yellow with patterns of green leaves, yet this is only seen in a small area because the rest is covered with white fabric perhaps used to save the fine material from fading in the light $^{69}$. In fact, this is the traditional way of dressing such cushions with white lace or transparent muslin in order to unify the row and hide the edges of each cushion; but not, as claimed earlier, as protection from the light.

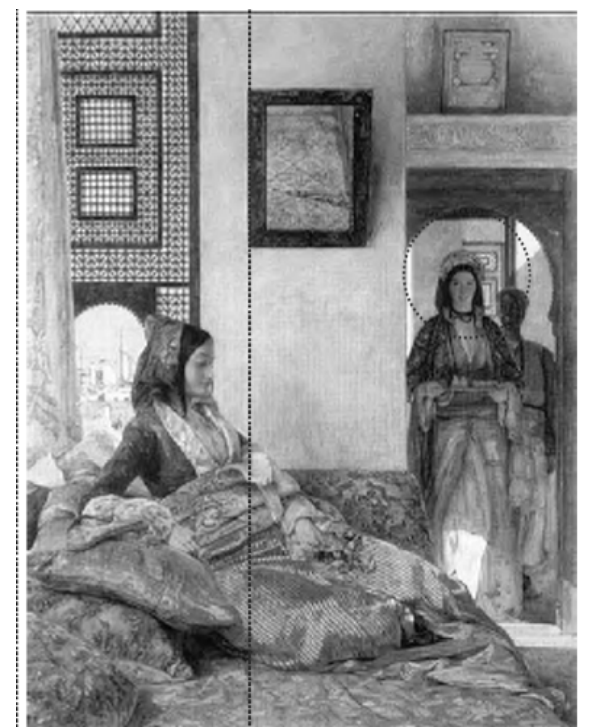

Figure 13. Life in the Harīm, Cairo, 1858

This style of furnishing of the harīm does not exist solely in Turkey. It was common in the Arab world by the nineteenth century, and has remained a fashionable trend until recently. JF. Lewis depicted a similar scene from Cairo in The Hareem (1851). He also depicts this type of seating with the same fabric in another picture with the same title An Oriental Interior, Constantinople, painted in 1863. However, he drew the same seating in the sketch of The Hareem, in 1850 (Figure 10).

Malcolm claims that JF. Lewis painted his harīm as a religious painting that elevates the status of the harīm women and makes a statement for the tolerance of Islam as an equal spiritual and civilised faith $^{70}$. John Mackenzie also argues that JF. Lewis was impressed by the manner in which religion entered the fabric of everyday life ${ }^{71}$. This may indicate JF. Lewis's awareness of the role of Islam in the fabric of the domestic life, which he attempted to demonstrate through his paintings; perhaps to introduce manners that could be adopted back home. Héléne Gill agrees that the wooden lattices, mashrabiyyah, are lovingly portrayed, not only because they presented technical problems of pattern, texture and light for JF. Lewis, but also because they represented architectural adornments that could be, and were being adopted in the West ${ }^{72}$. So, it is more than admiration of the harīm and the screening phenomena, it is rather a genuine attention to adopt such a concept. 
Reina Lewis argues that JF. Lewis painted Orientalism more closely resembles works by Frederick Arthur Bridgman and Frederick Goodall, both of whom indulged in several less explicit fantasies in their Oriental paintings, and who tended to present Islamic women in bourgeois Victorian terms $^{73}$. JF. Lewis depicts the harīm not just as a place for women, but also as a space where the family gathered and socialised. In the first harim scene, JF. Lewis depicts a child with the parents and the other wives of the household. These figures are portraits of JF. Lewis himself, his wife and Zulikha, who is believed to be JF. Lewis's housemaid ${ }^{74}$. In fact, the alcove of the screens of the harim becomes a theatre for daily social life, which is reflected in JF. Lewis's interpretation of women gathering behind lattice screens as a significant place inside the house.

A prominent motif in JF. Lewis's harīm scenes are the screens that filter light into the space. His fascination with these architectural features is reflected in the use of shadow to create a dramatic effect. The visual impact of these scenes is embodied in the golden threads covering different surfaces within the interior. The woodwork of the screens emphasises the contrast in colours with the interior as a background. It also provides warmth and absorbs the bright, strong sunlight entering from outside. The themes and the richness of the Islamic ornamentation are represented everywhere, with geometric motifs on the woodwork and floral designs on the fabrics.

The scene of Life in the harīm, Cairo, also places emphasis on an important aspect of Arab culture: hospitality. This setting highlights the experience of having a guest, with the lady of the house serving a coffee. Benjamin claims that the mirror and the entering woman's welcoming smile create an intimacy between the viewer and the scene $^{75}$. The woman entering is JF. Lewis's wife and the servant behind her could be 'Zulikha', the same person depicted in many of JF. Lewis's paintings. This depiction emphasises the pattern of using the space within the harim lattice window as a reception area. Guests and the lady of the house could enjoy coffee together and chat. JF. Lewis may have understood the notion of hospitality in Arab culture, especially among women. In Arab custom it is an honour for the host to serve the guest personally, even if the house is full of servants. The servant may prepare everything, but the lady of the house will carry it to the guest. However, even among wealthy people, the privilege of serving the guest also indicates the status of the guest in relation to the host.

According to an interpretation of this painting by Malcolm, the seated woman, possibly modelled on JF. Lewis's wife Marian, gazes thoughtfully at a bouquet of flowers in her lap. Malcolm then questions if the girl entering the room is another wife, thus suggesting polygamy, which was considered uncivilised by "Victorian viewers"76. In fact, the smile on the woman's face could not suggest such a situation. In Arab culture this would be seen differently ${ }^{77}$. On the one hand the seated woman may suggest that she has come for the first time to visit a friend or a neighbour, as she gives the impression of shyness in her eyes. The bunch of flowers could represent a gift to the lady of the house, as it is customary to bring something on one's first visit. On the other hand, the hostess would try to ease the visitor's anxiety and the smile would deliver this message. Therefore, interpreting the scene as two wives meeting, as Malcolm does, seems imaginary and overstated, without knowing JF. Lewis's intention.

In another interpretation, Benjamin argues that the Victorian audience was familiar with the idea of nosegays in Eastern harīms, which are used to communicate 'illicit messages'. The scene in this respect suggests that the young woman is dreaming of a lover outside the harim ${ }^{78}$. It seems that this is typical of the interpretation of any oriental scene, whether exercised by the artist or by 'ordinary' Victorian viewers at that time. harīm scenes, if they are not reflecting polygamy and the severity of male Muslims in keeping women for their own pleasure, have to show the potential immorality of the females of the house as a result of segregation ${ }^{79}$. This is the stereotypical thinking of what is being practiced behind these heavily screened harīm, and is the imaginary interpretation of an alien culture that reflects nothing but exotic and erotic manners. The above interpretations show the impact of the fantasy of the Arabian Nights.

In Life in the harīm, the mirror reflects the lattice of the window and reveals the unseen part of it. In both paintings the mirror is on the sidewall of the lattice window. In Arab culture it is highly unlikely that a mirror of such size would be located in this position. Culturally, what is the function of the mirror in this corner of the harīm area, especially in the seating area where the mirror may reflect the scene of the sitting area from different angles? If the mirror is for a purpose related to women and beauty it would be bigger and would definitely not be beside or close to the lattice window. The scene of Life in the harīm is the reverse of A Turkish School (1865). Comparing both scenes to The Hareem, Cairo, shows that they appear as a portion of this harim depiction. JF. Lewis repeatedly included the lattice windows in the majority of his paintings when he returned from Cairo. In each painting he depicted these screens from different vantage points, as if the house was filled with these screens and there was nothing but the screens. 
However, the lattice window in An Oriental Interior, Constantinople, is poorly depicted in terms of details and the notion of such screened windows. What is depicted is not a screened window, nor a hijāb device: it is more like a fixed screen that lacks architectural details. The fascination with such screens was still evident in the artist's mind, but the reconnection of its image had faded. This is similar to the painting of The Siesta (1876), when the screen enveloped and created the setting with no sign of the principle of the hijāb that lies behind the harīm screens. In The Siesta, JF. Lewis paints a woman asleep in her chamber. The pose of the woman and the location of the unbarred lattice to the ground suggest the possibility of approaching and gazing at the unaware woman. There is a sense that the viewer is an intruder on the woman's privacy, which would not be the case in Islamic culture. The space within the lattice window could be used as a sleeping area, but it would not have been used as such if the occupier were a woman. The scene shows the dilemma in JF. Lewis's mind between satisfying the public, and mainly the critic, and fulfilling his dreams, memories, and nostalgia for Islamic architecture and culture. The sense of light within the interior is not the major subject here; rather, the woman's position is of major importance. The harīm as a space and the lattice screens are only used as a stage or a background for such a pose ${ }^{80}$.

\section{Conclusion}

Even nowadays, the harīm, in its broadest sense retains the same position in popular understanding as it did among $19^{\text {th }}$ century Western Orientalists. The concept of the harim as the inner space in the Islamic and Arab house is well known among Western architectural scholars and Orientalists in particular. The image of the 'harīm' remains as a scene from Arabian Nights to be viewed and enjoyed, but never a reality scene for existing culture. Islamic culture has been transferred and snatched from its frame with no understanding of its culture values. This paper, however, argues that without an insider perspective and appropriate understanding of the complex and highly specific etymology of the term, popular and Orientalist conceptions of the harīm remain inadequate. This paper has detailed how the admiration of and fascination with this sacred place for women captured the imagination of the Orientalist painters of the $19^{\text {th }}$ century. John Frederick Lewis was not an exception among artists of his time. Despite his ten years living in Cairo experiencing the 'native' way of living, his fantasies of and fascination with the harīm is evident in most of his paintings and, as such, he represents a productive case study to reflect on $19^{\text {th }}$ century Western travellers' misunderstandings of the harīm as a both a place and as a wider concept. Finally, it is evident and beyond a shadow of a doubt that Islamic values which interwoven within a Muslim daily life cannot be interpreted without a genuine practice of Islam. Arminius Vambery ${ }^{81}$, the Hungarian Orientalist and explorer who experienced travelling among the Muslims of Central Asia, wrote on a certain occasion that "It may well be said that Christian travellers like Burchardt, Burton, Maltzahn and others have exhausted subjects relating to the Holy Places of Islam, but a Muslim sees more and better than any foreigner"82.

\section{Notes and References}

1 Inderpal Grewal. 1996. Home and Harem: Nation, Gender, Empire, and the Cultures of Travel. Durham, USA: Duke University Press.

2 Elizabeth Cooper. 1915. The harīm and the Purdah: Studies of Oriental Women. LondonUK: T. Fisher Unwin, Ltd. 26

3 Reina Lewis. 2000. "Harem and Hotels" in: Gender and Architecture. Ed., Louise Durning and Richard Wrigley. Chichester: John Wiley and Sons, Ltd. 172-174.

$4 \quad$ Alev Lytle Croutier. 1989. Harem - the World Behind the Veil. New York- USA: Abbeville Publisher.

5 The lesser pilgrimage to Makkah which is optional and can be taken at any time.

6 Az-Zubaidi, Zain-ul-Din Ahmad bin AbdulLateef. Summarized Sahih Al-Bukh"ri (ArabicEnglish). Trans. Muhammad Muhsin Khan. AlRiyadh: Darussalam, 1996. 1043-1047

7 hijāb is a broader term that means veiling and concealing and not just a woman's veil.

8 See Melman, 149, where some English studies refer to the term 'haremlik' instead of the ḥarīm.

9 Henry Yule \& AC.Burnell. 1903. Hobson-Jobson: A Glossary of Colloquial Anglo-Indian Words and Phrases, 2nd ed. Kent: Linguasia, 411.

10 See McGregor, 356, in saying that Zanana (Persian, zanana) adj. means women's (as in rooms, compartment, work, institution), women's department.

11 Andrew Petersen. 1996. Dictionary of Islamic Architecture. London: Routledge.

12 Gunther. 2002. Glossary of Indian Art, s. v. 'harem', and 'zenana'.

13 Ilay Cooper and Barry Dawson. 1998. Traditional Buildings of India. London: Thames \& Hudson Ltd.

14 Muslim communities in Patan and in Gujarat region have a great link with the Arabian Sea and trade route. See Doshi, 34-40.

15 Partha Mitter. 2001. Indian Art. (Oxford History of Art Series). Oxford: Oxford University Press. 102

16 It is also shown in the Leighton House website as a legitimate term, see The Royal Borough of Kensington and Chelsea Museum and Arts 
Service, Leighton House Museum at <http://www.rbkc.gov.uk/LHLeightonHouse/Ho useTour/arabhalltour17.asp>

17 Elizabeth Cooper. 1915. The harīm and the Purdah: Studies of Oriental Women. LondonUK: T. Fisher Unwin, Ltd. 26

18 Henry Yule and A.C.Burnell. 1903. HobsonJobson: A Glossary of Colloquial Anglo-Indian Words and Phrases, $2^{\text {nd }}$ ed. Kent: Linguasia, 744

19 R.S.McGregor, ed. 1997. Oxford - Hindi English Dictionary. 2nd ed. Oxford: Oxford University Press. 603

20 Suzanne Slesin and Stafford Cliff. 1990. Indian Style. London: Thames \& Hudson Ltd. 294

21 Az-Zubaidi, Zain-ul-Din Ahmad bin AbdulLateef. 1996. Summarized Sahih Al-Bukh"ri (Arabic-English). Trans. Muhammad Muhsin Khan. Al-Riyadh: Darussalam. 1043

22 Ahmad Al-zayat and Others. Ed. al-Mucjam alWasit, vol. 1, Cairo: Majmac al-Lughah alArabiyyah.

23 Alev Lytle Croutier. 1989. Harem - the World Behind the Veil. New York- USA: Abbeville Publisher. 13

24 It is also claimed that 'andarun' is the inner quarter reserved for close family members and female visitors, See Scarce, 32-38.

25 Elizabeth Cooper. 1915. The harīm and the Purdah: Studies of Oriental Women. LondonUK: T. Fisher Unwin, Ltd. 24-25

26 See Thornton, The Orientalists, 4. The East in this sense includes the Near, Middle East and Ottoman Turkey.

27 Sarah Graham-Brown. 1988. Images of Women: The Portrayal of Women in Photography of the Middle East 1860 - 1950. London: Quartet Books.134

28 Reina Lewis. 1996. Gendering Orientalism: Race, Femininity and Representation. London: Routledge.

29 Inderpal Grewal. 1996. Home and Harem: Nation, Gender, Empire, and the Cultures of Travel. Durham. USA: Duke University Press. 50

30 See <http://www2.ucsc.edu/culturalstudies/ PUBS/Inscriptions/vol_6/yegenoglu.html>

31 Alev Lytle Croutier. 1989. Harem - the World Behind the Veil. New York- USA: Abbeville Publisher. 41

32 Mary Walker, a British amateur artist who lived in Turkey for over thirty years, was commissioned to paint a number of portraits of the Sultan's family and wealthy elites. See Beaulieu and Roberts, ed., 191.

33 Sultana Zeïneb is believed to be the daughter of Muhammad Ali Pasha, who was a resident of Constantinople.

34 See Beaulieu and Roberts 191, 193 and 201.

35 Elizabeth Cooper. 1915. The harīm and the Purdah: Studies of Oriental Women. LondonUK: T. Fisher Unwin, Ltd. 164

36 These assertions are grounded in my point of view as a Muslim woman who has experienced and practiced the hijāb, and has been brought up valuing it in a holistic sense. Such a practice would not be experienced by non-Muslims.

37 Lloyd Llewellyn-Jones. 2000. "Women and Veiling in the Ancient Greek World." Ph.D. Cardiff University.297-298

38 See Lidia Sciama, "The problem of privacy in Mediterranean anthropology", 1981. It is stated on page 93 that "Privacy, which came powerfully into literary, and, later, into common use in the sixteenth century. This clearly has no parallel in Latin itself or in other neo-Latin languages".

39 Friedrich Ragette. 2003. Traditional Domestic Architecture of the Arab Region. Edition Axel Menges, ed. Sharjah. UAE: American University of Sharjah.75

40 Sarah Graham-Brown. 1988. Images of Women: The Portrayal of Women in Photography of the Middle East 1860 - 1950. London: Quartet Books. 75, 77.

41 See more in the neglect of religious issues and the biased opinions of scholars who come after Lane in Campo, "Orientalist Representations", 38.

42 Mark Crinson. 1996. Empire Building: Orientalism and Victorian Architecture. Manchester: Manchester University Press.

43 Briony Llewellyn. 1985. "Islamic Inspiration: John Frederick Lewis, Painter of Islamic Egypt" in: Sarah Macready and F.H. Thompson, ed. Influences in Victorian Art and Architecture. London: The Society of Antiquaries of London. 129-130

44 Briony Llewellyn. 1985. "Islamic Inspiration: John Frederick Lewis, Painter of Islamic Egypt" in: Sarah Macready and F.H. Thompson, ed. Influences in Victorian Art and Architecture. London: The Society of Antiquaries of London. 131

45 Briony Llewellyn. 1985. "Islamic Inspiration: John Frederick Lewis, Painter of Islamic Egypt" in: Sarah Macready \& F.H. Thompson, ed. Influences in Victorian Art and Architecture. London: The Society of Antiquaries of London. 131

46 Ezbakiya is named after the Emir Ezbek Ibn Tushtush. In 1798 when Napoleon's army occupied Cairo and settled in the area, they found some of the grandest houses of the ruling emirs and wealthy bourgeoisie. Later in the 1850 s the area was full of hotels to accommodate tourists and residents (Peltre, 97). The name is also written as, Azbakiyya, Ezbekiya or Ezbekeeyah. See Campo, The Other Sides of Paradise, 78.

47 See more on the house in Lewis, JF. Lewis, 22.

48 Miles Danby. 1995. Moorish Style. London: Phaidon Press Ltd. 47

49 These drawings including the plan of the house, sections and elevations are in the Victoria \& Albert Museum.

50 Thackeray, 209-211

51 Thomas Seddon (1821-1856) was born in London and was described as 'the purest preRaphaelite landscape painter'. Seddon went to 
Egypt in 1853 and to the Holy Land with William Hollman Hunt in 1854, he then returned to Egypt in 1856 and died there (Stevens, 227).

52 Mary Anne Stevens. Ed. 1984. The Orientalists, Delacroix to Matisse: European Painters in North Africa and the Near East. London: Royal Academy of Arts in Association with Weidenfeld \& Nicolson. 205

53 In some references it is written as Hhareem as in Benjamin, 79-81.

54 See more in Lewis, J. F. L., 39, and in Benjamin, 82, which stresses that The harīm setting is repeated for several of Lewis's imaginary harīim.

55 Roger Benjamin. 1997. Orientalism: Delacroix to Klee. Australia: Thames and Hudson. 80

56 F. Lewis wrote this in the Royal Scottish Academy Catalogue of the 27th Exhibition, 1853. See Benjamin, 80.

57 Benjamin, 79- 81. I have personally seen the original version of this painting in the Victoria \& Albert Museum, in 2005.

58 There is no date on this version, but according to Benjamin, the sketch is dated 1850 and is currently held in Melbourne, Australia. See more in Benjamin, 79.

59 The dog in Islam is highly prohibited unless used for security purposes. Islam has special way of cleaning; if the dog's mouth touches any cloth that could be used by human. "The Prophet (peace be upon him) said: The angels do not enter a house which contains a picture, a dog ... ". Sunan Abu-Dawud, Book 32, no 4140.2 Abu-Dawud, Sunan Abu-Dawud. Trans. Ahmad Hasan. University of Southern California. September 14, 2005. Digital copy. <http://www.usc.edu/dept/MSA/fundamentals /hadithsunnah/abudawud/032.sat.html>.

60 Jennifer Scarce. 1996. Domestic Culture in the Middle East. Scotland: National Museum of Scotland. 63

61 (Lane-Poole, vol. 2, 55)

62 Briony Llewellyn. 1985. "Islamic Inspiration: John Frederick Lewis, Painter of Islamic Egypt" in: Sarah Macready \& FH. Thompson, ed. Influences in Victorian Art and Architecture. London: The Society of Antiquaries of London. 133

63 Ruth Bernard Yealzell. 2000. Harems of the Mind: Passages of Western Art and Literature. London: Yale University Press. 225

64 Miles Danby. 1995. Moorish Style. London: Phaidon Press Ltd. 66

65 Ruth Bernard Yealzell. 2000. Harems of the Mind: Passages of Western Art and Literature. London: Yale University Press. 229-230

66 Briony Llewellyn. 1985. "Islamic Inspiration: John Frederick Lewis, Painter of Islamic Egypt" in: Sarah Macready and F.H. Thompson, ed. Influences in Victorian Art and Architecture. London: The Society of Antiquaries of London. 133

67 Jennifer Scarce. 1996. Domestic Culture in the Middle East. Scotland: National Museum of Scotland.
68 The Dakka or mastabah is a built-in seating area or a low wall used for seating. The mastabah is a similar element in the Arab world, as a raised seat or platform of stone or brick built against the front of the dokan (shop) or the main door of the house where men socialise and finish business.

69 See Malcolm, Hareem Life, Constantinople and Life in the Hareem, Cairo.

70 See Malcolm, “John Frederick Lewis".

71 John Mackenzie. 1995. Orientalism - History, Theory and the Arts. Manchester: Manchester University Press. 60-62

72 Héléne Gill. 2003. The Language of French Orientalist Painting, Studies in Art History vol. 6. UK: The Edwin Mellen Press Ltd. 204

73 Reina Lewis. 2006. "Rethinking Orientalism: Women, Travel and the Ottoman Harem", Journal of Islamic Studies 17. 75

74 Briony Llewellyn. 1985. "Islamic Inspiration: John Frederick Lewis, Painter of Islamic Egypt" in: Sarah Macready and F.H. Thompson, ed. Influences in Victorian Art and Architecture. London: The Society of Antiquaries of London.

75 Roger Benjamin. 1997. Orientalism: Delacroix to Klee. Australia: Thames and Hudson.

76 Malcolm, "Hareem Life, Constantinople and Life in the Hareem, Cairo". See more on the comparison with another painting Friendship Endangered by Frank Stone in the same year. Interestingly, the latter painting is interpreted as friendship whereas the former is related to polygamy, because the scene is Oriental.

77 This could reflect the Arabic way of interpreting the scene, as perceived by the author as a woman with awareness of related cultural issues within the domestic interiors of Arab culture, in which polygamy is still experienced.

78 Roger Benjamin. 1997. Orientalism: Delacroix to Klee. Australia: Thames and Hudson, 84

79 Reina Lewis.1996. Gendering Orientalism: Race, Femininity and Representation. London: Routledge. 111-112

80 Elizabeth Malcolm. "John Frederick Lewis, RA.: Self-Censorship in the Harem Paintings of JF. Lewis." Senior Thesis. Hartwick College, 1997. Electronic copy. http://www.angelfire.com/ ny4/ eamward/lewis.htm (accessed February 5, 2002).

81 Arminius or Hermann Vambery (1832-1913) was a Hungarian philologist and traveller. He went to Constantinople (1857-63) and learned several languages and dialects of Asia Minor and then traveled through Armenia and Persia in the dress of a native. He was a professor of Oriental languages at the University of Budapest from 1865 to 1905 and wrote many books on his travels and on languages and ethnology. The Columbia Electronic Encyclopedia, 6th ed. s.v. "Vambery" http://www.infoplease.com/ce6/ people/A0850398.html (accessed May 30, 2006)

82 See Eric Rosenthal, From Drury Lane to Mecca, 2nd ed. (Cape Town: Howard Timmins Ltd, 1982) 27. 